\title{
Heterotransplantation of Human Parathyroid Glands into Nude Mice
}

\author{
YujI TANAKA, HiROOMI FUNAHASHI, TsUNEO IMAI, JYUNICHI TOBINAGA, \\ HIROSHI MURASE, HIROYUKI ANDOH, MASAKI WADA, TAKAKO MATSUYAMA, \\ YOSHIHIRO TOMINAGA*, AND HIROSHI TAKAGI
}

The Department of Surgery II, Nagoya University School of Medicine, Nagoya 466, and

*The Organ Transplant Center, Nagoya Second Red Cross Hospital, Nagoya 466, Japan

\begin{abstract}
Heterotransplantation of human parathyroid tissues into nude mice was performed to investigate the characteristics of grafted tissues. Grafts prepared from hyperplasia, adenoma and normal glands which were resected at operation were implanted in the gluteus muscle of the recipient mice (female, KSNnu/nu strain). Graft function was evaluated by measuring human intact PTH concentrations in sera of the mice. Serum PTH concentrations 12 weeks after transplantation were correlated with the tissue volume in the mice which received one, two, four or eight pieces of $1 \mathrm{~mm}^{3}$ hyperplastic tissues. Changes in graft function were examined in the mice which received four grafts prepared from hyperplasia, adenoma or normal glands. Transplantation of parathyroid tissues resulted in an increase in PTH concentrations for 4 weeks, reaching a plateau thereafter. The level remained unchanged for 8 weeks. Serum PTH levels in the mice with grafts prepared from hyperplasia or adenoma were significantly higher than in those with grafts from normal glands, though without a significant difference between the mice with grafts from adenoma and from hyperplasia. Serum calcium levels were similar in all three groups. We also observed the response of grafted parathyroid tissue to a low calcium level in sera: there was higher PTH secretion four weeks after the administration of the low calcium diet. The success of heterotransplantation was histologically proven by the presence of grafts which were not atrophic in the muscle 12 weeks after transplantation. Nucleoli were found more frequently, and nuclear pleomorphism was observed in the cells of heterografts.
\end{abstract}

Key words: Parathyroid, Nude mouse, Heterotransplantation, PTH

(Endocrine Journal 42: 9-14, 1995)

THE PARATHYROID gland is the only tissue that can be autotransplanted among endocrine organs. Autotransplantation of parathyroid tissue is commonly used in the treatment of patients with primary or secondary hyperparathyroidism due to hyperplasia [1, 2]. Furthermore, various techniques for successful autotransplantation of normal parathyroid glands have also been devised in patients

Received: April 6, 1994

Accepted: September 30, 1994

Correspondence to: Dr. Yuji TANAKA, The Department of Surgery II, Nagoya University School of Medicine, 65 Tsurumai-cho, Showa-ku, Nagoya 466, Japan with thyroid cancer, since lymph node dissection jeopardizes the vascularity of parathyroid glands leading to postoperative hypoparathyroidism [3]. Although the results of autotransplantation are satisfactory in most cases, problems such as the recurrence of hyperparathyroidism due to graft hyperplasia or hypoparathyroidism due to failure of autotransplanted normal parathyroid gland to function does occur in a few cases [4-6].

In the present study, heterotransplantation of human parathyroid tissues into nude mice was performed to investigate the morphological and functional characteristics of grafted tissues and to investigate the characteristics of PTH secretion in 
the normal parathyroid gland, adenoma and hyperplasia. Although many studies examined the characteristics of grafted tissues, a few reports dealt with evaluation by measuring the serum human PTH concentration [7, 8].

\section{Materials and Methods}

Human parathyroid heterotransplantation into nude mice

Normal, adenomatous and hyperplastic parathyroid glands were resected at operation from patients with primary and severe secondary hyperparathyroidism, respectively. The glands were immediately put into saline solution at $4{ }^{\circ} \mathrm{C}$. Normal parathyroid glands obtained from patients with primary hyperparathyroidism were histologically examined to exclude hyperplasia or adenoma.

The tissue was cut into $1 \mathrm{~mm}^{3}$ pieces and put into pockets prepared in the gluteus muscle of the recipient mice (female nude mice of KSNnu/nu strain). The pockets were then closed with $6-0$ nylon sutures. All the animals were maintained in sterile cages with free access to water and food pellets throughout the experiment. The normal diet contained $1.7 \mathrm{~g}$ of calcium per $100 \mathrm{~g}$. In order to investigate low calcium levels in sera to grafts, a low calcium diet which contained $7.2 \mathrm{mg}$ of calcium per $100 \mathrm{~g}$ was given to twelve mice 8 weeks after transplantation.

Blood samples were obtained by puncturing the tail vein before transplantation and every two weeks thereafter. Twelve weeks after transplantation, the mice were bled by cardiac puncture. Heterografts were resected and examined histologically.

\section{Determination of intact (1-84) human PTH}

PTH concentrations were determined in aliquots of sera that had been stored at $-80^{\circ} \mathrm{C}$. A doubleantibody immunoradiometric assay (allegro Intact PTH; Nichols Institute Diagnostics, San Juan Capistrano, Calif.) was used. Concentrations of serum total calcium were measured with a Hitachi (Hitachi, Ltd. Tokyo, Japan) 736-60 automatic analyzer.

\section{Statistical analysis}

Data were expressed as the mean \pm SD. The unpaired Student's $t$ test was used to compare serum PTH and calcium concentrations.

\section{Results}

\section{Differences in graft function with volume of grafts}

The relation between the volume of implanted parathyroid tissue and serum PTH levels was evaluated (Fig. 1). Four groups of four mice each received one, two, four or eight pieces of $1 \mathrm{~mm}^{3}$ hyperplastic parathyroid tissue respectively. In the mice in the control group $(n=4)$, no graft was implanted. PTH concentrations 12 weeks after heterotransplantation were correlated with the tissue volume; $97 \pm 32 \mathrm{pg} / \mathrm{ml}$ in one piece group, 185 $\pm 58 \mathrm{pg} / \mathrm{ml}$ in two pieces group, $510 \pm 67 \mathrm{pg} / \mathrm{ml}$ in the four pieces group and $1112 \pm 64 \mathrm{pg} / \mathrm{ml}$ in the eight pieces group. Human PTH was not detected in the mice without heterografts, indicating that this assay did not cross-react with mouse PTH.

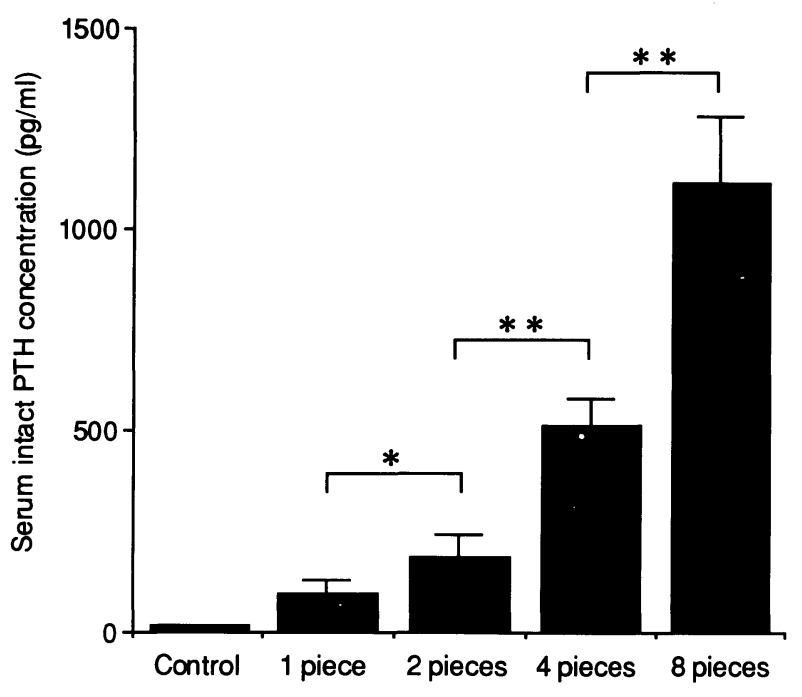

Fig. 1. Differences in serum human PTH concentrations with volume of grafts. In the mice of control group, no graft was implanted. Values are means \pm SD. ${ }^{*} P<0.05$ and ${ }^{* *} P<0.001$, when serum PTH concentrations in the mice with one graft and two grafts, two and four grafts or four and eight grafts were compared by unpaired Student's $t$ test. 
Graft function at different intervals after transplantation

\section{1) Normal diet group}

The graft function was examined by measuring PTH concentrations every two weeks after heterotransplantation. Grafts prepared from normal glands, adenoma and hyperplasia were implanted into four, four and six mice, respectively. Each mouse received four pieces of parathyroid tissue 1 $\mathrm{mm}^{3}$ in size. In the mice in the control group, no graft was implanted. As shown in Fig. 2, transplantation of parathyroid tissues resulted in an increase in the PTH concentration for 4 weeks, and reached a plateau thereafter. The level remained unchanged for 8 weeks. Serum PTH levels in the mice with normal gland grafts were significantly lower than in those with adenomatous or hyperplastic gland grafts, though there was no significant difference between serum PTH levels in the latter two groups at any phase of the experiment. Even if serum PTH levels in the mice with normal gland grafts and those with adenomatous or hyperplastic gland grafts were different, their changes were similar. Human PTH could not be detected in sera at any phase of the experiment in the mice in the control group.

Although the PTH concentrations 12 weeks after transplantation were about $500 \mathrm{pg} / \mathrm{ml}$ in the mice with adenomatous and hyperplastic gland grafts and about $100 \mathrm{pg} / \mathrm{ml}$ in the mice with normal gland grafts, serum calcium concentrations were similar in the three groups. Furthermore, there was no significant difference in serum calcium concentrations between these three groups and the control group (Table 1).

2) Low calcium diet group

Grafts prepared from normal glands, adenoma and hyperplasia were implanted into 3 groups of four mice each. All mice were given a normal diet

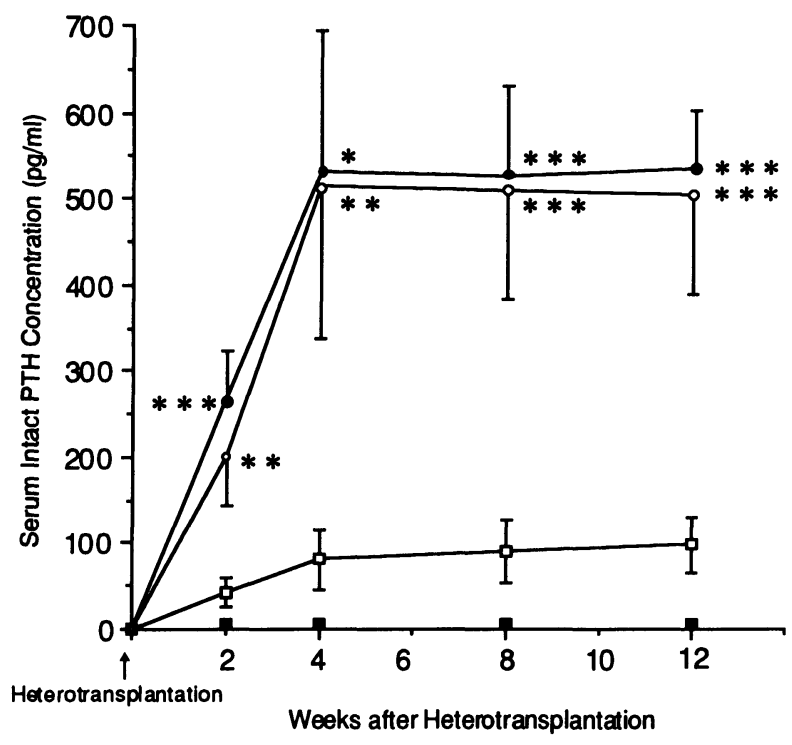

Fig. 2. Changes of serum intact PTH concentrations with passage of time. Normal gland grafts, open squares; adenomatous grafts, closed circles; hyperplastic grafts, open circles; control group, closed squares. ${ }^{*} P<0.05,{ }^{* *} P<0.01,{ }^{* * *} P<0.001$, when serum PTH concentrations in the mice with normal gland grafts and in those with adenomatous or hyperplastic grafts were compared by unpaired Student's $t$ test .

for eight weeks after transplantation and later switched over to a low calcium diet which was continued for 4 weeks more.

The serum calcium concentration in the sera of 12 mice was $7.9 \pm 0.47 \mathrm{mg} / \mathrm{d} l$ (mean $\pm \mathrm{SD}) 8$ weeks after transplantation and was $5.7 \pm 0.51 \mathrm{mg} / \mathrm{d} l$ (mean \pm SD) 12 weeks after transplantation. There was a significantly lower concentration of calcium after the low calcium diet $(P<0.001)$.

Serum PTH concentrations in sera 8 weeks after transplantation were $90 \pm 35 \mathrm{pg} / \mathrm{ml}$ in the mice transplanted with normal gland grafts, $415 \pm 150$ $\mathrm{pg} / \mathrm{ml}$ in those with hyperplastic grafts and $460 \pm$ $70 \mathrm{pg} / \mathrm{ml}$ in those with adenomatous grafts. They

Table 1. Serum intact PTH and calcium concentrations 12 weeks after transplantation

\begin{tabular}{lccc}
\hline $\begin{array}{c}\text { Type of } \\
\text { parathyroid pieces }\end{array}$ & $\begin{array}{c}\text { No. } \\
\text { of mice }\end{array}$ & intact PTH concentration $(\mathrm{pg} / \mathrm{ml})$ & $\begin{array}{c}\text { Serum } \\
\text { calcium concentration }(\mathrm{mg} / \mathrm{d} l)\end{array}$ \\
\hline None (Control) & 4 & $3 \downarrow$ & $7.8 \pm 0.24$ \\
Normal gland & 4 & $97 \pm 33$ & $7.8 \pm 0.29$ \\
Adenoma & 4 & $535 \pm 65$ & $7.8 \pm 0.33$ \\
Hyperplasia & 6 & $503 \pm 114$ & $7.9 \pm 0.20$ \\
\hline
\end{tabular}


were significantly higher 12 weeks after transplantation: $226 \pm 87 \mathrm{pg} / \mathrm{ml}, 698 \pm 184 \mathrm{pg} / \mathrm{ml}$ and $785 \pm$ $110 \mathrm{pg} / \mathrm{ml}$ respectively $(P<0.05, P<0.01, P<0.01)$ (Fig. 3).

\section{Histological findings in the grafted tissue}

Grafted tissues were resected 12 weeks after transplantation, and histological findings were evaluated by hematoxylin and eosin staining (Fig. 4). As shown in Fig. 4B, the success of heterotransplantation of human parathyroid tissues was histologically proven by the presence of grafts which were not atrophic. However, nucleoli were found more frequently, and nuclear pleomorphism was observed in the cells of heterografts. Mitotic figures were found rarely in some specimens. Fat cells were often found in the normal gland grafts (Fig. 4B-1).

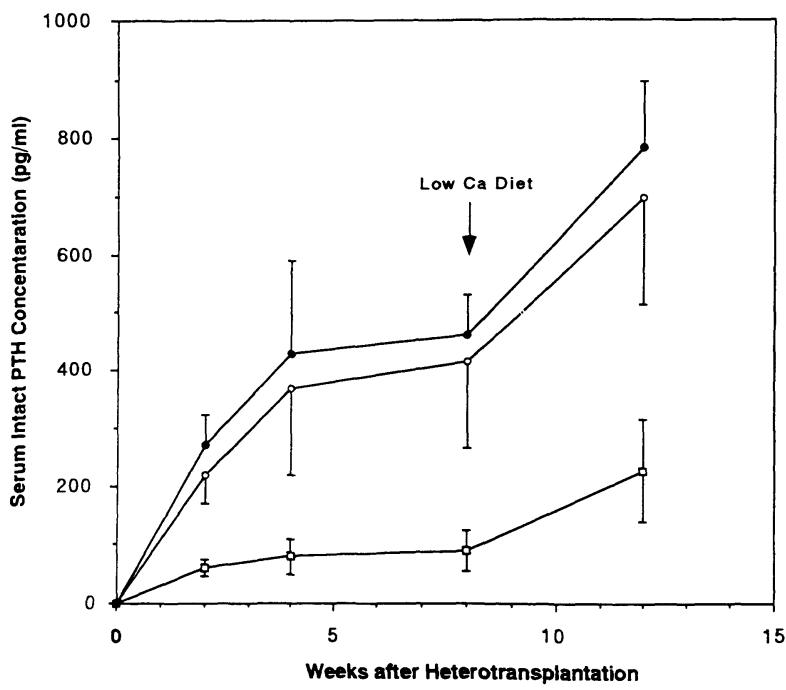

Fig. 3. Change in serum intact PTH concentrations to a low calcium diet. Normal gland grafts, open squares; adenomatous grafts, closed circles; hyperplastic grafts, open circles.
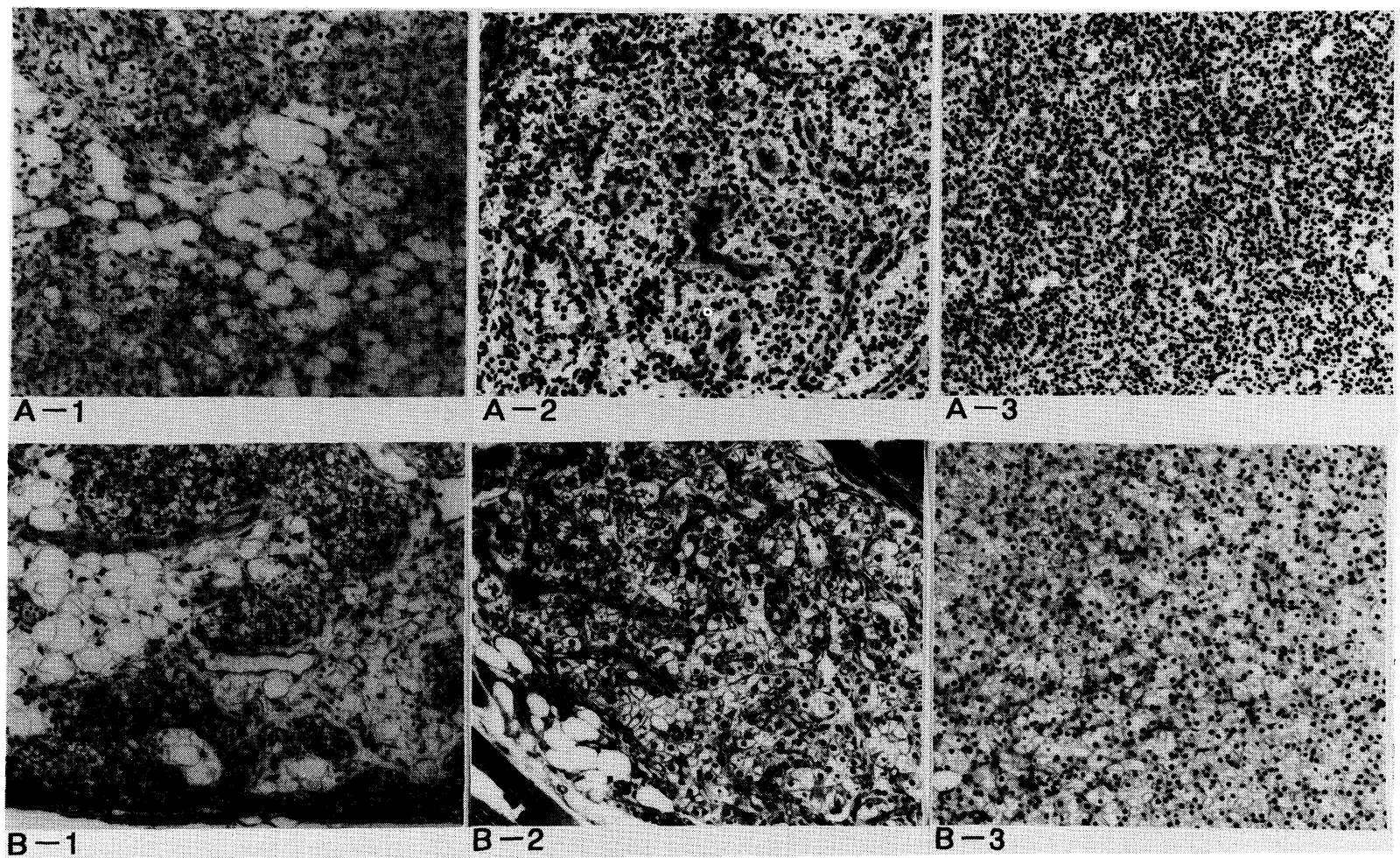

Fig. 4. Microscopic findings ( $\times 200)$. A, Parathyroid tissues used for heterotransplantation; $B$, Heterografts resected 12 weeks after transplantation. A and B-1, Normal parathyroid; A and B-2, Adenoma; A and B-3, Hyperplasia. 


\section{Discussion}

Many studies have been conducted on PTH synthesis by parathyroid cells by evaluating the expression of PTH mRNA, and secretion by both in vivo study with dogs or rats and in vitro study of cell cultures [9-19]. The early experiments in vivo concerned the successful outcome of transplantation of the parathyroid glands. With rats, Gittes and Radde transplanted many supernumerary normal glands into recipients of the isogenic strain, and considered this experimental model to be an endogenous hyperparathyroidism model because of the increased serum calcium [19]. They suggested that hyperparathyroidism was mainly due to abnormal proliferation of hormone secretory cells because supernumerary normal glands reached a hyperfunctional state. Recently, Schachter et al. directly documented graft function by measuring human PTH concentrations in sera from nude mice which received transplants of human parathyroid tissues [7].

Based on the results of experiments in animals, Lahey for the first time clinically autotransplanted parathyroid glands into sternocleidomastoid muscle following thyroidectomy [20]. Since Wells et al. demonstrated the function of grafts prepared from hyperplastic glands of patients with primary or secondary hyperparathyroidism by measuring serum PTH concentrations, the autotransplantation of the parathyroid glands has come into wide clinical use [1]. Long-term follow-up has identified two unsolved problems: hypoparathyroidism in patients with autografts of normal parathyroid glands and hyperparathyroidism in those with autografts of hyperplastic glands [4, 21, 22]. Subsequent experimental studies on parathyroid transplantation in vivo have aimed at clarifying the mechanism of hypo- or hyperfunction of grafts.

The present study was aimed at the basic evaluation of heterotransplantation of human parathyroid tissues into nude mice. Our results indicated that serum PTH concentrations were directly correlated with the volume of implanted tissues. These data support the suggestion of Gittes et al. that abnormal cellular proliferation is attributable to hyperparathyroidism. Furthermore, when normal parathyroid glands are autotrans- planted in patients with thyroid cancer, hypoparathyroidism may not occur if a sufficient volume of parathyroid tissues are transplanted [3]. On the other hand, serum PTH concentrations in the mice with normal gland grafts were much lower than those in the mice with hyperplastic or adenomatous grafts of the same volume. This suggests that autotransplantation of normal glands is more likely to induce hypoparathyroidism than that of hyperplasia.

In autotransplantation of hyperplastic glands, the mechanism of graft-dependent hyperparathyroidism is not yet understood [2, 4, 22]. Although hyperplasia or adenoma had greater capability for PTH secretion, it was revealed that PTH secretion did not increase with the passage of time after transplantation but became steady four weeks after transplantation. This observation was not reported before. The fact that PTH secretion of hyperplastic gland grafts reached a plateau after transplantation suggests that graft-dependent hyperparathyroidism may not occur unless the circumstances of the host are changed. Some stimulants may be needed to make the grafts hyperfunctional [23]. The human hormone did not have the adequate bioactivity in the host in the experimental model [8]. We therefore investigated what changes the function of the graft undergo by changing the circumstances of the host, such as the administration of a low calcium diet. Mice transplanted with normal, adenomatous and hyperplastic gland grafts were given a low calcium diet from 8 weeks after the transplantation i.e. four weeks after the PTH level reached a plateau. We observed a remarkable rise in the PTH level, and a low level of calcium after 12 weeks of transplantation in all groups of mice.

This experimental model is very simple and useful in investigating the various characteristics of grafted parathyroid tissue.

\section{Acknowledgment}

This work was supported in part by Grant-InAid 03807077 for Scientific Research from the Ministry of Education, Science, and Culture, Japan, and in part by the IMANAGA Medical Foundation, Japan. 


\section{References}

1. Wells SA, Gunnells JC, Shelburne JD, Schneider AB, Sherwood LM (1975) Transplantation of the parathyroid glands in man: Clinical indications and results. Surgery 78: 34-44.

2. Takagi H, Tominaga Y, Uchida K, Yamada N, Kawai M, Kano T, Morimoto T (1984) Subtotal versus total parathyroidectomy with forearm autograft for secondary hyperparathyroidism in chronic renal failure. Ann Surg 200: 18-23.

3. Funahashi $H$, Satoh $Y$, Imai $T$, Ohno $M$, Narita $T$, Katoh M, Tanaka Y, Tobinaga J, Andoh H, Miyazaki K, Murase H, Takagi H (1993) Our technique of parathyroid autotransplantation in operation for papillary thyroid carcinoma. Surgery 114: 92-96.

4. Rothmund M, Wagner PK, Schark C (1991) Subtotal parathyroidectomy versus total parathyroidectomy and autotransplantation in secondary hyperparathyroidism: A randomized trial. World J Surg 15: 745-750.

5. Klempa I, Frei U, Röttger P, Schneider M, Koch KM (1984) Parathyroid autografts-morphology and function: Six year's experience with parathyroid autotransplantation in uremic patients. World J Surg 8: 540-546.

6. Shaha AR, Burnett C, Jaffe BM (1991) Parathyroid autotransplantation during thyroid surgery. J Surg Oncol 46: 21-24.

7. Schachter P, Burkley N, Oyama H, Christy MGL Jr, Lobaugh B (1989) Primary hyperparathyroidism: A new experimental animal model. Surgery 106: 9971001.

8. Schachter P, Christy MD, Leight GS Jr, Lobaugh B (1990) Function in athymic nude mice of parathyroid heterografts from patients with primary hyperparathyroidism and secondary hyperparathyroidism. Surgery 108: 1040-1046.

9. Fukagawa M, Kaname S, Igarashi T, Ogata E, Kurokawa K (1991) Regulation of parathyroid hormone synthesis in chronic renal failure in rats. Kidney Int 39: 874-881.

10. Tanaka $Y$, Seo H, Tominaga $Y$, Funahashi $H$, Matsui $\mathrm{N}$, Takagi $\mathrm{H}$ (1993) Factors related to the recurrent hyperfunction of autografts after total parathyroidectomy in patients with severe secondary hyperparathyroidism. Surg Today 23: 220-227.

11. Sun F, Ritchie CK, Hassager C, Maercklein P, Fitzpatrick A (1993) Heterogeneous response to calcium by individual parathyroid cells. J Clin Invest 91: 595-601.

12. Wallfelt $\mathrm{CH}$, Larsson $\mathrm{R}$, Gylfe E, Ljunghall S, Rastad J, Åkerström G (1988) Secretory disturbance in hyperplastic parathyroid nodules of uremic hyperparathyroidism: Implication for parathyroid autotransplantation. World J Surg 12: 431-438.

13. Ljunghall S, Benson L, Wide L, Åkerström G, Rastad J (1988) Improved differential diagnosis of hypercalcemia by hypocalcemic stimulation of parathyroid hormone secretion. World J Surg 12: 496-502.

14. Brown EM, Brennan MF, Broadus AE, Marx SJ, Gardner DG, Spiegel AM, Downs RW Jr, Attie MF, Aurbach GD (1979) Human parathyroid autografts: Comparison of function in vivo and in vitro. JCEM 48: 648-654.

15. Weber CJ, Russell J, Costanzo MK, Karp F, Benjamin M, Hardy MA, Feind CR (1992) Relationships of parathyroid hormone, parathyroid secretory protein, parathyroid hormone messenger RNA, parathyroid secretory protein $\mathrm{mRNA}$, and replication in human parathyroid adenoma and secondary hyperplasia tissues and cultures. Surgery 112: 10891095.

16. Tominaga $Y$, Tanaka $Y$, Sato $K$, Numano $M$, Uchida K, Falkmer U, Grimelius L, Johansson H, Takagi H (1992) Recurrent renal hyperparathyroidism and DNA analysis of autografted parathyroid tissue. World J Surg 16: 595-603.

17. Niederle B, Horandner H, Roka R, Woloszczuk W (1989) Morphologic and functional studies to prevent graft-dependent recurrence in renal osteodystrophy. Surgery 106: 1043-1048.

18. Demeter JG, De Jong SA, Oslapas R, Ernst K, Hessel P, Jarosz H, Smith M, Nayyar R, Lawrence AM, Paloyan E (1991) High phosphate diet-induced primary hyperparathyroidism: An animal model. Surgery 110: 1053-1060.

19. Gittes RF, Radde IC (1966) Experimental model for hyperparathyroidism: Effect of excessive numbers of transplanted isologous parathyroid glands. J Urol 95: 595-603.

20. Lahey FH (1926) The transplantation of parathyroids in partial thyroidectomy. Surg Gynecol Obstet 42: 508-509.

21. Baumann DS, Wells SA (1993) Parathyroid autotransplantation. Surgery 113: 130-133.

22. Malmaeus J, Benson L, Johansson H, Ljunghalls, Rastad J, Åkerström G, Oberg K (1986) Parathyroid surgery in the multiple endocrine neoplasia Type I syndrome: Choice of surgical precedure. World J Surg 10: 668-672.

23. Naveh Many T, Marx R, Keshet E, Pike JW, Silver J (1990) Regulation of 1, 25-dihydroxyvitamin D3 receptor gene expression by 1,25-dihydroxyvitamin D3 in the parathyroid in vivo. J Clin Invest 86: 19681975. 